\title{
Electronic Learning May Improve the Teaching and Learning of Mathematics and Science in Marginalized Schools in Nakivale Refugee Settlement, Uganda: A Baseline Analysis
}

\author{
Angella Musiimenta ${ }^{1}$, Wilson Tumuhimbise ${ }^{1}$, Michael Nankunda ${ }^{1}$, Elly Bangumya ${ }^{1}$, Justus Atuhaire ${ }^{1}$, Robert \\ Mugonza $^{1}$, Phiona Kobutungi ${ }^{1} \&$ Aaron T Mugaba ${ }^{1}$ \\ ${ }^{1}$ Information Technology Department, Mbarara University of Science and Technology, Mbarara, Uganda \\ Correspondence: Angella Musiimenta, PhD, Information Technology Department, Mbarara University of Science \\ and Technology, Mbarara, P.O BOX, 653, Mbarara, Uganda. Tel: 256-776-820-598.
}

Received: June 7, 2019

Accepted: July 15, 2019

Online Published: July 22, 2019

doi:10.20849/jed.v3i2.611

URL: https://doi.org/10.20849/jed.v3i2.611

\begin{abstract}
Background: Over the years, mathematics and sciences have been performed poorly worldwide. There is an overwhelming high failure rates of mathematics and sciences in the marginalized schools found in Nakivale refugee settlement in Uganda. Electronic (e)-learning tools could be promising interactive strategies for teaching mathematics and sciences. There is lack of studies documenting educational challenges in the refugee settlement, and how e-learning can address the challenges.

Objective: To identify the challenges experienced in teaching and learning mathematics and sciences in schools found in Nakivale refugee settlement, and explore the potentials of using e-learning to address the identified challenges.

Methods: We employed a parallel mixed methods study design that utilized focus group discussions and surveys. We purposively conducted a focus group discussion with the 17 mathematics/science teachers that we had trained (in e-learning) from 6 schools in Nakivale refugee settlement. We also administered surveys to 267 learners and mathematics/science teachers of the six participating schools.

Results: Educational challenges reported by participants are: 1) lack of access to modern teaching and learning resources, 2) Leaners' negative attitudes towards mathematics and science, 3) overwhelming number of learners in class. 4) Lack of ICT pedagogical skills. They anticipated that e-learning could potentially: 1) enable unlimited and flexible access to educational resources, and 2) enhance engagement, interest and understanding of learning concepts. They however worried about the availability of sufficient technological infrastructure (e.g. internet, computers, and electricity) and skills to use the application.
\end{abstract}

Conclusion: E-learning may enable unlimited and flexible access to educational resources, and enhance engagement, interest and understanding of learning concepts, which could potentially improve performance in mathematics and sciences in otherwise marginalized schools.

Keywords: e-learning, multimedia, videos, ICT, education, mathematics, sciences, refugee camp

\section{Introduction}

Over the years, mathematics and sciences have been performed poorly worldwide. Schools in developed countries continue to lead in mathematics performance while developing countries continue to experience exponential decline in mathematics performance (Mullis et al., 2015). This trend is expected to continue if nothing is done. Quality studies documenting mathematics performance in Sub Saharan Africa are rare. 1n Zambia more than $40 \%$ of the pupils don't get the lowest pass mark at national level examination (Kafata and Mbetwa, 2016) while in Kenya mathematics has long been poorly performed (Mbugua et al., 2012). There is an overwhelming high failure rates of mathematics both at primary and secondary levels in Uganda (Kiwanuka et al., 2015). Reports of teachers themselves failing mathematics during their training are not uncommon in Uganda (Mukhaye, 2018). Reasons surrounding the poor performance in mathematics include shortage of modern learning materials, poor quality, experience and exposure of mathematics teachers, negative attitude of students towards learning of mathematics, and poverty (Tella, 2008, Lawsha Mohamed and Hussain Waheed, 
2011, Alade, Kuku and Osoba, 2017, Graven, 2014).

Mathematics and sciences improves the human mind, develops mans' rational thoughtfulness, improves one's intellect, and develops critical thinking and problem solving skills, (Genlott and Grönlund, 2016, Kafata and Mbetwa, 2016), which are fundamental in making inventions and effective decisions. Passing mathematics and science at lower levels is a prerequisite for pursuing mathematics/science subjects at high levels, which provides a basis to contribute to scientific inventions and developments.

Using Information Communication Technology (ICT) (such as computers, internet, projectors, and multimedia videos/audios) in teaching and learning (commonly known as e-learning) is reported to have raised learners' enthusiasm and curiosity in mathematics in various countries such as Malaysia, United Kingdom and USA (Zakaria and Khalid, 2016), facilitated collaborative learning in Malaysia (Ally et al., 2017), improved performance in Taiwan (Sung, Chang and Liu, 2016), facilitated creative mathematical thinking in the United States of America (Ke, 2014). In Kenya the use of GeoGebra, an ICT application was perceived as being useful for teaching and learning of abstract mathematical topics like geometry (Mukiri Mwingirwa and Khakasa Miheso-O' Connor, 2016). E-learning has been reported to motivate and improve the learning process in Uganda (Ali et al 2013). Overall, the use of ICT/e-learning in teaching and learning mathematics and sciences particularly in low resource settings, however, has not been well explored. Moreover, studies focusing on assessing e-learning implementation in schools found in a refugee setting are rare. The purpose of this baseline study is to identify the challenges experienced in teaching and learning mathematics and sciences in Ugandan primary and secondary schools located in Nakivale refugee settlement. We also explore the potentials of using e-learning to address the identified challenges.

\section{Method}

\subsection{Study Setting}

Found in the rural district of Isingiro (south-western), Nakivale refugee settlement is the largest settlement in Uganda, and is the $8^{\text {th }}$ biggest refuge settlement in world which was established in 1960. It has a population of over 100,000 people (from various parts of the world including: Rwanda, Congo, Burundi, Somalia, Eritrea, Sudan, and Kenya). Young people account for $60 \%$ the refugee population, who are victims of forced displacement, wars, and conflicts, tortures, and human rights abuses. Quality education can help refugee children regain their hope for the future. Nakivale refugee settlement has only five government-owned primary schools, and only one secondary school, which is supported by Windle International. These schools are: Kabazana, Kahirimbi, Kashojwa, Rubondo, Juru primary schools and Nakivale Secondary School. A part from Nakivale Secondary School which had 10 working computers and electricity, the rest of the schools had no computers, internet, and electricity at a time of conducting this baseline assessment. Mathematics is currently the poorest done subject in the settlement ( $80 \%$ average failure rate), yet it is a prerequisite for passing other subjects, and subsequent enrolment to better courses and careers. Due to lack of basic health science education, many girls continue to drop out of schools due to teenage pregnancies. There are also high levels of classroom absenteeism due to preventable sicknesses, and poor health conditions that affect effective learning.

\subsection{Study Design and Sampling}

This baseline study employed a parallel mixed methods study design that utilized focus group discussions and surveys. We purposed to conduct a focus group discussion with all the primary six and senior one teachers that participated in a 5-days orientation workshop that took place at Mbarara University of Science and Technology. Of the 20 mathematics and basic science teachers that were trained from Kabazana, Kahirimbi, Kashojwa, Rubondo, Juru primary schools and Nakivale Secondary School., only 17 participated in the focus group discussion that was held at Nakivale Secondary School. The Investigators administered baseline surveys to 284 participants made up of 267 primary six pupils and senior one students, and 17 mathematics/science teachers of the six participating schools. We used stratified random sampling technique, a probability sampling technique where the researcher divides the entire population into different subgroups called strata, and then randomly selects the final subjects proportionally from the different strata (Krejcie and Morgan 1970). Our sampling strategy aimed at including relatively balanced representatives for gender and nationality.

\subsection{E-learning Application Overview}

This e-learning application is an open source application that can be accessed via http://www.mathnakivale.com/. The application is being implemented in six schools (Kabazana, Kahirimbi, Kashojwa, Rubondo, Juru primary schools and Nakivale Secondary School) all located in Nakivale refugee settlement in Isingiro district south western Uganda. The application is accessed using the Desktop computers, via the internet, projected over LCD 
Projectors, and powered by generators provided by e-learning project, which is funded by SPIDER (the Swedish Programme for Information Communication Technology in Developing and Emerging Regions) based in Stockholm University. It is composed of digitized contents (audio, video, interactive quizzes, and text) of primary six mathematics which were developed based on the curriculum developed by the Uganda National Curriculum Development Centre. Mathematics topics covered include sets, algebra, operations, measurements, calculus, geometry, and logic and number theory. The e-learning application also consists of digitized contents for basic health sciences including sanitation, personal hygiene, sexual and reproductive health, management of adolescent life, management of basic and communicable diseases like typhoid, malaria without excluding safe, and clean water. Although the application covered basic health sciences, this paper mainly reports on the mathematics aspects of the intervention. Using the applications, teachers can upload teaching resources, access digital contents inform of videos and text, assess students, and communicate to the students using the chartroom. While students can access the learning materials, do the assessment, and read and respond to teachers' communications.

\subsection{Study Procedures}

Before conducting a focus group discussion and administering questionnaires, the teachers and pupils were oriented on using the E-learning application. The orientation covered accessing, uploading for the teachers and downloading content by the students and pupils. Each participant was given a chance to use the application to get acquainted of its operation to guide the focus group discussion process.

\subsection{Data Collection}

We carried out a focus group discussion composed of 17 primary six and senior one science/mathematics teachers in Jan 2019. The discussion lasted 60 minutes and was digitally recorded using a digital recorder and later transcribed. During the discussion, the investigators elicited participants' opinions about the challenges faced in teaching and learning mathematics/science in their respective schools and participants' perceptions about the use of e-learning application in addressing the identified challenges. We also carried out a baseline assessment in March 2019 where questionnaires were administered to 267 primary six pupils and senior one students from the six participating schools. The Unified Theory of Acceptance and Use of Technology (UTAUT) model guided the formulation of the survey questions due its ability to predict a substantial portion of the acceptance of health information technology (Venkatesh et al 2003). The model posits that technology adoption is influenced by four major constructs as perceived by an individual user 1) performance expectancy/perceived usefulness; 2) effort expectancy/percieved ease of use; 3) social norms (i.e., how others perceive the individual's use of the intervention); and 4) facilitating conditions (i.e. the availability of technical and organisational infrastructure to support use of the intervention).

\subsection{Analysis}

We used inductive content analysis (Miles, Huberman and Saldana, 2014), to derive categories describing and summarizing the challenges experienced by participants and how e-learning can potentially address the challenges. We reviewed and discussed $20 \%$ of transcripts for content relevant to challenges and anticipated benefits. We then assembled a codebook from the identified concepts, using an iterative process, which included developing codes to represent content, writing operational definitions, and selecting illustrative quotes. Following completion of the codebook, we applied codes using NVIVO 11. Differences in coding were harmonized through discussion. Participants' socio demographic details and preferences were analyzed descriptively using STATA 13.

\subsection{Ethical Reviews}

All participants provided signed informed consent before study participation. Ethical approval was obtained from the Institutional Review Committee of Mbarara University of Science and Technology, and the Uganda National Council for Science and Technology. 


\section{Results}

Table 1. Social demographics details of the participants

\section{Learners}

\begin{tabular}{lccc}
\hline & Teachers & Pupil & Students \\
\hline Age group & 0 & $48(77.4 \%)$ & $14(22.6 \%)$ \\
\hline $10-14$ yrs & $1(0.05 \%)$ & $82(44.8 \%)$ & $100(54.6 \%)$ \\
\hline $15-19 y r s$ & 0 & $1(25.0 \%)$ & $3(75.0 \%)$ \\
\hline $20-24 y r s$ & $4(80.0 \%)$ & $1(20.0 \%)$ & 0 \\
\hline $25-29 y r s$ & $6(66.7 \%)$ & $2(22.2 \%)$ & $1(11.1 \%)$ \\
\hline $30-34 y r s$ & $4(80.0 \%)$ & $1(20.0 \%)$ & 0 \\
\hline $35-39 y r s$ & $1(100.0 \%)$ & 0 & $61(50.8 \%)$ \\
\hline $40-44$ yrs & & & $59(49.2 \%)$ \\
\hline Gender & $12(2.21 \%)$ & $92(64.8 \%)$ & $26(31.0 \%)$ \\
\hline Male & $4(0.68)$ & $50(35.2 \%)$ & $10(34.5 \%)$ \\
\hline Female & & & $58(53.2 \%)$ \\
\hline Country of origin & $14(16.7 \%)$ & $44(52.4 \%)$ & $6(66.7 \%)$ \\
\hline Uganda & 0 & $19(65.5 \%)$ & 0 \\
\hline Rwanda & 0 & $51(46.8 \%)$ & $19(48.7 \%)$ \\
\hline Democratic Republic of Congo & 0 & $3(33.3 \%)$ & $1(100.0 \%)$ \\
\hline Somalia & 0 & $7(100.0 \%)$ & \\
\hline South Sudan & $2(5.1 \%)$ & $18(46.2 \%)$ & 0 \\
\hline Burundi & 0 & & 0 \\
\hline Ethiopia & & 0 & \\
\hline & & & \\
\hline
\end{tabular}

Survey Results

Table 2. Perceived usefulness of E learning

\begin{tabular}{llllll}
\hline Statement & $\begin{array}{l}\text { Strongly } \\
\text { agree } \\
\mathbf{n}(\%)\end{array}$ & $\begin{array}{l}\text { Agree } \\
\mathbf{n}(\%)\end{array}$ & $\begin{array}{l}\text { Disagree } \\
\mathbf{n}(\%)\end{array}$ & $\begin{array}{l}\text { Strongly } \\
\text { disagree } \\
\mathbf{n}(\%)\end{array}$ \\
\hline $\begin{array}{l}\text { E-Learning application could improve performance in } \\
\text { mathematics and science }\end{array}$ & $209(73.6)$ & $60(21.1)$ & $7(2.5)$ & $8(2.8)$ \\
\hline $\begin{array}{l}\text { E-learning application could enhance engagement and } \\
\text { understanding of mathematics and science }\end{array}$ & $191(67.3)$ & $71(25.0)$ & $15(5.3)$ & $7(2,5)$ \\
\hline $\begin{array}{l}\text { E-learning application could enable unlimited access to } \\
\text { educational resources }\end{array}$ & $210(73.9)$ & $53(18.7)$ & $10(3.5)$ & $11(3.9)$ \\
\hline $\begin{array}{l}\text { E-learninng application could enable flexibility in teaching } \\
\text { and learning }\end{array}$ & $212(74.6)$ & $53(18.7)$ & $10(3.5)$ & $9(3.2)$ \\
\hline $\begin{array}{l}\text { E-learning application could make teaching and learning } \\
\text { mathematics and science interesting. }\end{array}$ & & & & & \\
\hline
\end{tabular}

Table 2 above indicates that the majority of participants strongly agreed that using the e-learning application could improve performance in mathematics and science $(n=209,73.6 \%)$, enhance engagement and understanding of mathematics and science $(n=191,67.3 \%)$, enable unlimited access to educational resources $(n=210,73.9 \%)$, 
allow flexibility in teaching and learning $(\mathrm{n}=212,74.6 \%)$, could make teaching and learning mathematics and sciences interesting $(\mathrm{n}=210,77.5 \%)$.

Table 3. Perceived ease of the use of E learning applications

\begin{tabular}{lllll}
\hline Statement & $\begin{array}{l}\text { Strongly } \\
\text { agree n (\%) }\end{array}$ & $\begin{array}{l}\text { Agree } \\
\mathbf{n}(\%)\end{array}$ & $\begin{array}{l}\text { Disagree } \\
\mathbf{n}(\%)\end{array}$ & $\begin{array}{l}\text { Strongly } \\
\text { Disagree } \\
\text { n (\%) }\end{array}$ \\
\hline E-learning resources are easy to use and follow & $162(57.0)$ & $90(31.7)$ & $19(6.7)$ & $13(4.6)$ \\
\hline E-Learning contents are easy to upload and download & $90(31.7)$ & $80(28.2)$ & $73(25.7)$ & $41(14.4)$ \\
\hline E-learning application is flexible and interactive & $155(54.6)$ & $72(25.4)$ & $26(9.2)$ & $31(10.9)$ \\
\hline $\begin{array}{l}\text { I am willing to use the e-learning application in my daily } \\
\text { teaching routines }\end{array}$ & $205(72.2)$ & $57(20.1)$ & $10(3.5)$ & $12(4.2)$ \\
\hline
\end{tabular}

As shown in Table 3 above, the majority of participants strongly agreed that e-learning resources are easy to use and follow ( $\mathrm{n}=162,57 \%)$, e-learning contents are easy to upload and download $(\mathrm{n}=90,31.7 \%)$, e-learning application is flexible and interactive $(\mathrm{n}=155,54.6 \%)$, and were willing to use the e-learning application in their daily teaching routines $(\mathrm{n}=205,72.2 \%)$.

Table 4. Facilitating conditions for continued use

\begin{tabular}{lllll}
\hline Statement & $\begin{array}{l}\text { Strongly } \\
\text { agree n(\%) }\end{array}$ & Agree n(\%) & $\begin{array}{l}\text { Disagree } \\
\mathbf{n}(\mathbf{\%})\end{array}$ & $\begin{array}{l}\text { Strongly } \\
\text { disagree } \\
\mathbf{n}(\mathbf{\%})\end{array}$ \\
\hline $\begin{array}{l}\text { I have resources (e.g. internet, computers) } \\
\text { necessary to use E- learning application }\end{array}$ & $36(12.7)$ & $55(19.4)$ & $77(27.1)$ & $116(40.8)$ \\
\hline $\begin{array}{l}\text { E-learning is compatible with traditional } \\
\text { learning and teaching }\end{array}$ & $144(50.7)$ & $86(30.3)$ & $37(13.0)$ & $17(6.0)$ \\
\hline $\begin{array}{l}\text { I have enough time to use E- learning } \\
\text { application }\end{array}$ & $139(48.8)$ & $54(19.0)$ & $58(20.4)$ & $33(11.6)$ \\
\hline
\end{tabular}

Table 4 above indicates that the majority of the participants strongly disagreed that they have resources (e.g. internet, computers) necessary to use e-learning application $(n=116,40.8 \%)$, while the majority of the participants strongly agreed that E-learning is compatible with traditional learning and teaching, $(\mathrm{n}=144,50.7 \%)$, and that they have enough time to use E- learning application ( $\mathrm{n}=139,48.8 \%)$.

Table 5. Social norms about using E-learning for teaching and learning

\begin{tabular}{lllll}
\hline Statement & $\begin{array}{l}\text { Strongly agree } \\
\mathbf{( \% )}\end{array}$ & $\begin{array}{l}\text { Agree } \\
(\mathbf{\%})\end{array}$ & $\begin{array}{l}\text { Disagree } \\
(\mathbf{\%})\end{array}$ & $\begin{array}{l}\text { Strongly disagree } \\
\mathbf{( \% )}\end{array}$ \\
\hline $\begin{array}{l}\text { Fellow teachers/students/pupils think I should } \\
\text { use E-learning }\end{array}$ & $180(63.4)$ & $79(27.8)$ & $19(6.7)$ & $6(2.1)$ \\
\hline $\begin{array}{l}\text { E-learning users have high social status and are } \\
\text { more prestigious }\end{array}$ & $201(70.8)$ & $55(19.4)$ & $12(4.2)$ & $16(5.6)$ \\
\hline $\begin{array}{l}\text { School administration welcome the idea of using } \\
\text { E-learning }\end{array}$ & $180(63.4)$ & $62(21.8)$ & $19(6.7)$ & $23(8.1)$ \\
\hline $\begin{array}{l}\text { Available policies and politics may hinder quick } \\
\text { adoption of E-learning }\end{array}$ & $80(28.2)$ & $54(19.0)$ & $54(19.0)$ & $96(33.8)$ \\
\hline
\end{tabular}

As shown in Table 5 above, the majority of participants strongly believed that their fellow 
teachers/students/pupils think I should use e-learning ( $\mathrm{n}=180,63.4 \%)$, e-learning users have high social status and are more prestigious ( $\mathrm{n}=201,70.8 \%$ ), and that school administration welcomes the idea of using e-learning $(\mathrm{n}=180,63.4 \%)$. The majority strongly disagreed that the prevailing policies and politics within the schools may hinder quick adoption of e-learning $(\mathrm{n}=96,33.8 \%)$.

\section{Overview of qualitative research results}

\section{Teaching and Learning Challenges}

Participants reported the following challenges associated with teaching and learning mathematics and science: 1) Lack of access to internet and modern libraries, 2) Lack of ICT pedagogical skills, 3) Negative attitudes about mathematics and science, and 4) Overwhelming number of learners in class.

\section{Lack of access to internet and modern libraries}

Teachers pointed out that access to modern libraries, and internet for researching about important teaching resources, was impossible in Nakivale refugee settlement. Consequently, they reported that they did not have access to modern teaching resources for their students/pupils.

"Many of us teachers lack access to good text books to help us prepare our teaching materials. We also have no access to internet, which would help us to access useful teaching resources for our students."

\section{Lack of ICT pedagogical skills}

Participants confessed that before they participated in the computer skills training, they did not have the necessary computer skills to enable them integrate Information Communication Technology (ICT) in teaching and learning, and utilize the internet to access teaching resources.

"Save for the training you gave us, many of us lacked internet and computer skills. The world is moving so fast with internet, so if we cannot use the internet, we will be left behind in this information era".

\section{Negative attitudes towards Mathematics and Sciences}

Participants reported that learners have negative attitudes about mathematics and sciences which includes the perceptions that mathematics and sciences are hard, girls' perceptions about their inability to excel in mathematics and sciences, and general lack of interest in education among learners in the refugee settlement. They attributed the lack of interest in learning to the challenges that learners experience including forced displacement, and human right abuses.

Many of our students have negative attitudes about mathematics and science. This is very common among our pupils especially the girls; many girls believe they cannot do well in these subjects, so they tend to leave them for the boys who also generally do not perform well. May be the nature of our pupils contributes; you see these are children that have gone through a lot; displacements, wars, harassment, violence, etc, so their interest in education is generally low. So they don't want to study things they perceive to be hard for them.

\section{Overwhelming number of learners in class}

Participants reported that the number of learners in class was rather overwhelming. This not only limited teachers in giving individual attention to learners, but also limited their ability to practically demonstrate concepts in class. They reported that the big numbers also slowed their teaching leading to less content coverage.

"We have a big challenge of huge numbers in a class; For example here in Nakivale secondary, we have 445 students in senior one alone. Although they are put into streams, still each stream has about 110 students. You know with mathematics and science, it needs enough time for handling each student individually, but moving around class with such a big number to reach on every student is hard so, you can't give students the necessary attention, and you cannot deliver exactly what you wanted to deliver".

\section{Potentials of e-learning}

Participants highlighted the potential benefits of ICT in addressing the challenges experienced in teaching and learning mathematics and science. These are: allowing unlimited and flexible access to teaching and learning resources, and enhancing learners' engagement, understanding, and interest.

\section{Allowing unlimited and flexible access to teaching and learning resources}

Teachers stressed that e-learning would enable them access the teaching and learning resources that they would otherwise not be able to access. They narrated that teachers would use the internet to access teaching resources, and research more about mathematics and science. Teachers narrated that the internet-based nature of the 
e-learning application would make it possible to access content irrespective of their geographical locations. They also perceived the internet that would enable students use their own time to learn more about the concepts that they might have not grasped in class.

\begin{abstract}
"Using e-learning will give us an opportunity to get good teaching content for mathematics and science since it uses the internet. Otherwise, it is hard to get such information elsewhere since we lack text books. It will also enable me access the content from wherever I will be. In fact, this will also help students use the system to revise in their own time since not every one learns from class."
\end{abstract}

\title{
Enhancing learners' engagement, interest, and understanding
}

Teachers reported that the multimedia nature of the e-Learning application that is composed of videos and audios will enhance learners' engagement, understanding and interest. They mentioned that the incorporated videos and audios will motivate students to use the application, which will encourage students to learn mathematics and sciences while at the same time enjoying watching the videos and listening to the audios.

They felt this approach may improve regular classroom attendance among the learners as some will come to enjoy the videos and audios.

"It is good that you included videos and audios in the e-learning application. Since videos are musical, the learners will enjoy while learning at the same time. This will encourage learners to regularly attend school in order to listen to the videos especially those that like music." Even being able to demonstrate what you are teaching in class with a video, and a projector will help them get a clear understanding.

\section{Discussion}

Teachers reported the following challenges associated with teaching and learning mathematics and science: 1) Lack of access to internet and modern libraries, 2) Lack of ICT pedagogical skills, 3) Negative attitudes about mathematics and science, and 4) Overwhelming number of learners in class.

Teachers and learners anticipated that the e-learning application could: 1) enable unlimited and flexible access to mathematics educational resources, 2) enhance engagement, interest and understanding of mathematical concepts, which could potentially improve performance in mathematics and sciences. They believed that their peers and school administration could support the use of an e-learning application for teaching and learning mathematics and sciences. They however worried about the availability of sufficient technological infrastructure (e.g. internet, computers, and electricity) and skills to use the application. What follows is the discussion of these concepts in relation to the current educational challenges identified.

E-learning's ability to provide flexible and unlimited access to modern access to modern teaching and learning resources will enable teachers use modern resources in preparing their lessons that can be used for effective classroom delivery. This accessibility is not only facilitated by the digital contents inform of videos and text which are incorporated in the application, but also the contents that teachers regularly upload to the application. The online nature of the application makes it possible to access the contents irrespective of one's geographical location, while at the same time allowing independent thinking. This allows learners to learn at their own pace allowing learners to grasp contents of the subjects according to their brain strength, for example online and offline contents can be paused at any time and repeated to understand the concept, (something that cannot be done when using face-to-face interaction), thereby allowing self-pacing, which is more satisfying and less stressful. Self-paced learning is particularly helpful in such a refugee setting where learning from class might be hard given the overwhelming number of learners in class, coupled with unfamiliarity of learning environments specially for the new comers of the refugee settlement. Accessing educational resources online can potentially be an alternative to traditional libraries, which, after all, are lacking in Nakivale refugee settlement. Access to modern resources could subsequently improve learners' academic performance in these otherwise marginalized schools.

However, limited internet connections could constrain accessibility to the educational contents. Currently, there is no cable internet in Nakivale refugee settlement. To enable internet access, we provided mobile internet modems (MTN and Africel) to teachers, which were regularly loaded with three months' internet data for accessing the application, watching, downloading, and uploading contents or taking learners through the application. However, there were fears that the three months' internet data could be exhausted before the three months, thereby limiting the accessibility of the e learning application. To minimize internet data, we supplemented the online version of the application with the offline version accessed through computers, DVD players, and projector screens. This could enable schools to utilize the application without internet connections. 
However, the offline version could limit interactivity, and constrain possibilities of uploading new contents, and using chart rooms.

Other potential limitations to accessibility of the e-learning application include lack of enough computers. Although we provided 4-5 computers to each school, they were not enough to serve the learners given that the average number of learners in primary six of each school were 108, yet none of these schools had a single computer of their own before. Nakivale secondary school had about 10 donated computers, which made it a total of 14 computers after receiving the four e-learning computers. However, 14 computers were still not enough since the number of students in the benefiting class (senior one) was 445. Like many other rural schools in Uganda, all the five beneficiary primary schools have no access to electricity to run the e-learning application equipment such as computers, projectors, and DVD players. Only Nakivale Secondary School, which is mainly funded by Windle International have access to electricity. We gave each school a power generator and regularly provided fuel to run the generator. To minimize fuel usage, schools put on the generators only during the mathematics/science class times when students are being taken through the application, which could limit application accessibility. The lack of ICT pedagogy skills was mitigated by providing training to teachers and learner peer educators in both basic computer skills and using the e-learning application. Such training is reported to positively influence the use of ICT in teaching and learning in secondary schools (Gil-Flores, Rodríguez-Santero, and Torres-Gordillo 2017).

The multimedia nature of application that includes the use of interactive videos could spur learners' engagement, interest, and understanding of mathematical concepts that would otherwise be hard to grasp. This could improve learners' ability to relate some of the abstract mathematics/science concepts with real life experiences. Illustrating such concepts using videos could facilitate visual learning that is interesting for learners, can easily be followed, and boosts understanding. Teaching using multimedia technology has been shown to be interesting and inspiring to learners (Hwang, Hung, and Chen 2014). This visual learning could potentially motivate learners to consistently attend classes, thereby reducing the current high rates of school absenteeism, dropout rates, and negative attitudes towards education among young people within Nakivale refugee settlement. Consequently, this could improve learners' performance in mathematics, which is currently the most failed subject in schools in Nakivale refugee camp. There is evidence of a positive relationship between access to e-learning and young people's academic performance in mathematics (Papadakis, Kalogiannakis, and Zaranis 2017).

The main strength of this study is that it identifies important insights from teachers and learners in marginalized schools located in a refugee settlement. These insights can inform the development of an e-learning application to meet the educational needs of such vulnerable and hard-to-reach populations. The study used a mixed-methods approach to collect both closed- and open-ended data. In addition, because the study was conducted in a rural sub-Saharan African area and population, it has implications for similar settings.

This study is limited by the fact that we asked participants about perceptions before they could use the e-learning application in real life. Although we practically demonstrated the use of the application to all participants, participants were not able to describe actual experiences using the application as part of their daily routine. Lastly, findings could be vulnerable to social desirability because participants self-reported their views.

In sum, e-learning may enable unlimited and flexible access to educational resources, and enhance engagement, interest and understanding of learning concepts, which could potentially improve performance in mathematics and sciences. The application provides a promising alternative or complementary approach to teaching and learning mathematics and sciences that could potentially overcome educational challenges experienced in a refugee settlement. As e-learning technologies proliferates, understanding how they are perceived by prospective users is critical to developing applications that are acceptable, feasible and effective in improving academic performance in this otherwise hard-to-reach population. Findings from this baseline study informed the design of an e-learning application for mathematics and basic health science education, which is currently being implemented in primary and secondary schools in Nakivale refugee settlement. An end-line study will be carried out to assess the acceptability, feasibility, and preliminary impact of the application on mathematics/science performance.

\section{Acknowledgements}

The authors would like to acknowledge SPIDER (Swedish Programme for ICT in Developing and Emerging Regions) for funding (Dnr: SU - 323 - 5.1.2- 0419 -17) this study. We appreciate Windle International for supplementing our onsite coordination of the adoption and implementation of the e-learning application. We thank UNHCR, and official of the Ugandan Prime Minister, for the administrative support accorded to us in 
implementing the e-learning application. We appreciate school heads, teachers, and students for finding time to integrate and utilize the e-learning application amidst their busy school routines.

\section{References}

Agyeyi, D. D., \& Voogt, J. (2011). ICT use in the teaching of mathematics: Implications for professional development of pre-service teachers in Ghana. Education and Information Technologies, 16(4), 423-439. https://doi.org/10.1007/s10639-010-9141-9

Alade, O. M., Kuku, O. O., \& Osoba, A. (2017). Factors Influencing Candidates' Performance in English Language and Mathematics at West African Senior School Certificate Examination. International Journal of Evaluation and Research in Education, 6(3), 243-251. https://doi.org/10.11591/ijere.v6i3.pp243-251

Ali, G., Haolader, F. A., \& Muhammad, K. (2013). The role of ICT to make teaching-learning effective in higher institutions of learning in Uganda. International Journal of Innovative Research in Science, Engineering and Technology, 2(8), 4061-4073.

Ally, M. et al. (2017). Use of Tablet Computers to Improve Access to Education in a Remote Location. Journal of Learning for Development, 4(2), 221-228. Retrieved from http://ezproxy.lib.uconn.edu/login?url=https://search.ebscohost.com/login.aspx?direct=true\&db=eric\&AN= EJ1149172\&site $=$ ehost-live

Daily Monitor. Primary school teachers fail Mathematics (no date). Retrieved 4 January 2019, from https://www.monitor.co.ug/News/National/Primary-school-teachers-fail-Mathematics/688334-4318222-qhq njp/index.html

Genlott, A. A., \& Grönlund, Å. (2016). Closing the gaps - Improving literacy and mathematics by ict-enhanced $\begin{array}{llll}\text { collaboration. Computers \& Education, } \quad \text { Pergamon, } & \text { 99, }\end{array}$ https://doi.org/10.1016/J.COMPEDU.2016.04.004

Gil-Flores, Javier, Javier Rodríguez-Santero, \& Juan-Jesús Torres-Gordillo. (2017, March). Factors That Explain the Use of ICT in Secondary-Education Classrooms: The Role of Teacher Characteristics and School Infrastructure. Computers in Human Behavior, 68, 441-49. https://doi.org/10.1016/J.CHB.2016.11.057

Graven, M. H. (2014). Poverty, inequality and mathematics performance: the case of South Africa's post-apartheid context. ZDM, Springer Berlin Heidelberg, 46(7), 1039-1049. https://doi.org/10.1007/s11858-013-0566-7

Hwang, G.-J., Hung, C.-M., \& Chen, N.-S. (2014). Improving Learning Achievements, Motivations and Problem-Solving Skills through a Peer Assessment-Based Game Development Approach. Educational Technology Research and Development, 62(2), 129-45. https://doi.org/10.1007/s11423-013-9320-7

Kafata, F., \& Mbetwa, S. K. (2016). An Investigation Into The Failure Rate In Mathematics And Science At Grade Twelve (12) Examinations And Its Impact To The School Of Engineering: A Case Studyof Kitwe District Of. International Journal of Scientific \& Technology, 5(8).

Ke, F. (2014). An implementation of design-based learning through creating educational computer games: A case study on mathematics learning during design and computing. Computers \& Education, Pergamon, 73, 26-39. https://doi.org/10.1016/J.COMPEDU.2013.12.010

Kiwanuka, H. N. et al. (2015). Factors affecting Mathematics achievement of first-year secondary school students in Central Uganda. South African Journal of Education, 35(3), 1-16. https://doi.org/10.15700/saje.v35n3a1106

Lawsha Mohamed, \& Hussain Waheed. (2011). Secondary students' attitude towards mathematics in a selected school of Maldives Institute of Education. International Journal of Humanities and Social Science, 1(15), 277-281.

Mbugua, Z. K. et al. (2012). Factors Contributing To Students' Poor Performance in Mathematics at Kenya Certificate of Secondary Education in Kenya: A Case of Baringo County, Kenya. Centre for Promoting Ideas, USA. Retrieved 4 January 2019, from http://karuspace.karu.ac.ke/handle/20.500.12092/1703

Miles, M., Huberman, A., \& Saldana, J. (2014). Qualitative data analysis. Retrieved 4 January 2019, from https://books.google.com/books?hl=en\&lr=\&id=3CNrUbTu6CsC\&oi=fnd\&pg=PR1\&dq=qualitative+resear $\mathrm{ch}+$ data+analysis\&ots $=$ Lh5-moUR2h\&sig=N4LsdBzAchxKVhnJ53tFaCZXKno

Mukhaye, D. (2018). Primary school teachers fail Mathematics. Daily Monitor, Feb. 25. Retrieved 5 June 2019, from 
https://www.monitor.co.ug/News/National/Primary-school-teachers-fail-Mathematics/688334-4318222-qhq njp/index.html

Mukiri Mwingirwa, I., \& Khakasa Miheso-O’ Connor, M. (2016). Status of Teachers' Technology Uptake and Use of GeoGebra in Teaching Secondary School Mathematics in Kenya. International Journal of Research in Education and Science (IJRES), 2(2), 286-294.

Mullis, I. V. S. et al. (2015). Timss. TIMSS 2015 International Result in Mathematics. https://doi.org/10.1002/yd.20038

New Evidence on What Educational Technology Solutions Work for Refugees and Displaced Populations (no $\begin{array}{lllll}\text { date). } & \text { Retrived } & 3 & \text { January } & \text { from }\end{array}$ https://www.ictworks.org/edutech-refugees-displaced-populations/\#.XC4Mplz7TIU

Nkula, K., \& Krauss, K. (2015). The integration of ICTs in marginalized schools in South Africa: Considerations for understanding the perceptions of in-service teachers and the role of training, (2014), 241-261. Retrieved from http://www.developmentinformatics.org/conferences/2014/papers/20-Nkula-Kirsten.pdf

Krejcie, R. V., \& Morgan, D. W. (1970). Determining sample size for research activities. Educational and psychological measurement, 30, 607-610.

Sangrà, A., \& González-Sanmamed, M. (2010). The role of information and communication technologies in improving teaching and learning processes in primary and secondary schools. ALT-J, 18(3), 207-220. https://doi.org/10.1080/09687769.2010.529108

Skryabin, M. et al. (2015). How the ICT development level and usage influence student achievement in reading, mathematics, and science. Computers \& Education, Pergamon, 85, 49-58. https://doi.org/10.1016/J.COMPEDU.2015.02.004.

Sung, Y.-T., Chang, K.-E., \& Liu, T.-C. (2016). The effects of integrating mobile devices with teaching and learning on students' learning performance: A meta-analysis and research synthesis. Computers \& Education, Pergamon, 94, 252-275. https://doi.org/10.1016/J.COMPEDU.2015.11.008

Tella, A. (2008). Teacher Variables As Predictors of Academic Achievement of Primary School Pupils Mathematics Adedeji TELLA. International Electronic Journal of Elementary Education, 1(1), 16-33.

Ul-Amin, S. N. (2010). An Effective use of ICT for Education and Learning by Drawing on Worldwide Knowledge, Research, and Experience: ICT as a Change Agent for Education.

UNICEF. (2018). Uganda Humanitarian Situation Report. Retrieved 21May 2019, from https://reliefweb.int/report/uganda/unicef-uganda-humanitarian-situation-report-january-june-2018

Venkatesh, V., Morris, M. G., Davis, G. B., \& Davis, F. D. (2003). User acceptance of information technology: Toward a unified view. MIS Quarterly, 425-478.

Zakaria, N. A., \& Khalid, F. (2016). The Benefits and Constraints of the Use of Information and Communication Technology (ICT) in Teaching Mathematics. Creative Education, Scientific Research Publishing, 7(11), 1537-1544. https://doi.org/10.4236/ce.2016.711158

\section{Copyrights}

Copyright for this article is retained by the author(s), with first publication rights granted to the journal.

This is an open-access article distributed under the terms and conditions of the Creative Commons Attribution license (http://creativecommons.org/licenses/by/4.0/). 